\title{
Japanese fellowships go begging despite \$2,000-a-month pay
}

\section{Tokyo}

Do young US scientists not want to come to Japan? Or are they simply unaware that there are now one hundred postdoctoral fellowships available for visits to Japan's government-run research institutes?

Figures released last week reveal a severe shortage of applicants for new Japanese fellowship schemes, originally designed to counter US criticism of the imbalance in exchange of scientists between the two countries.

During the re-negotiations of the Science and Technology Agreement, completed only in June, the United States lambasted Japan because far more Japanese researchers go to the United States than US researchers to Japan. Japan's response was a series of fellowship schemes whose supply outstrip demand.

Thus Japan's Science and Technology Agency (STA) devised a new postdoctoral fellowship scheme offering 100 fellowships a year. Half of the places were reserved for US scientists, with the remainder divided among 10 countries (Australia, Canada, West Germany, Finland, France, italy, Netherlands, New Zealand, Sweden, Switzerland and Britain) and the European Community.

The Japanese Prime Minister Takeshita also arranged for the Foreign Ministry to donate $\$ 4.8$ million to the US National Science Foundation (NSF) to set up a fellowship fund for about 50 to 100 US scientists to make long-term visits to Japan, while the Ministry of Education, Science and Culture announced 100 "new" fellowships, again half going to the United States.

The ministry's fellowships, which are administered by the Japan Society for Promotion of Science (JSPS), have been squeezed out of existing bilateral programmes with Britain, France and West Germany by cutting the duration of the European fellowships from two years to one. For years, the European and particularly the British fellowship schemes have suffered from a chronic lack of applicants.

The new US fellowships schemes seem to be heading for the same fate. By last week, more than a month after the first deadline for applications (already extended), there were only four firm applicants for the US quota of 50 STA fellowships, according to Toyokazu Fukui of the agency's international affairs division. And there are only eight applications for the 50 fellowships available for US scientists under the JSPS scheme, according to Alexander DeAngelis, head of NSF's Tokyo office.

The conditions of the awards are unlikely to be to blame.The STA fellow- ship, for periods of six months to two years, provides a tax-free monthly allowance of about $\$ 2,000$ ( 270,000 yen), plus additional payments to help with housing, travel and relocation. The JSPS fellowships offer similar conditions. The STA fellowships are tenable at any of over 100 government laboratories.

What has gone wrong? DeAngeles says it is too early to judge. He says the NSF office in Washington, which handles the US applications, distributed information on the fellowships to about 3,700 heads of departments at universities across the United States. He says that NSF has had more than 1,500 inquiries by letter or telephone, that the number of telephone calls is increasing and that he is optimistic that applications will pick up by the spring.

Part of the problem may be insufficient publicity. For years the Royal Society of London was able to fill only about half of the places under its scheme with JSPS. But after taking new measures to publicize the scheme in 1986 (Nature 323, 571; 1988),

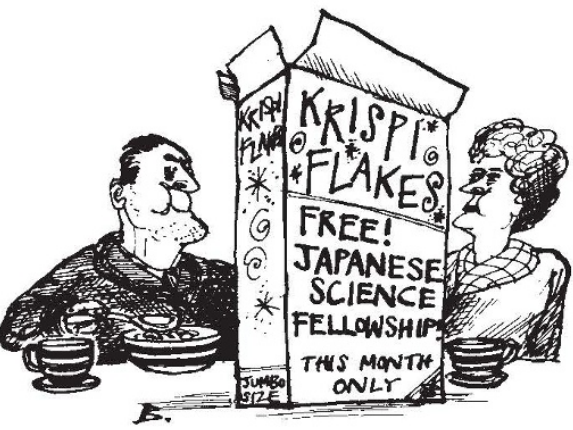

applications began to rise and the scheme is now oversubscribed by more than two to one, according to John Grote, Science Officer at the British Council in Tokyo.

Inadequate notice and poor timing may also be to blame, according to DeAngeles. He says pamphlets describing full details of the STA fellowships were printed by STA only a little over a month ago, after the initial deadline of 1 August. Information may thus have been distributed to US universities when many researchers were on vacation. But Fukui says details of the fellowships were first described "informally" to western government officals in March and "officially" at the end of June.

STA officials are now worried. The agency has just applied for extra funds to boost the number of fellowships to 130 in fiscal year 1989 and the Ministry of Education has made a similar request to increase the JSPS fellowships to 130 . But if this year's quotas cannot be filled by the end of December, when next year's budget must be fixed, the Ministry of Finance will be unwilling to provide the increases.

David Swinbanks

\section{One-week wait}

THE National Aeronautics and Space Administration (NASA) announced last Friday that the space shuttle Discovery would be launched on Thursday, 29 September, at about $\mathbf{1 0 . 0 0}$ am in Florida. The announcement was delayed until after Hurricane Gilbert had moved west and no longer threatened the Johnson Space Flight Center in Houston, Texas. D.L.

\section{Ozone flyer}

WEST Germany is to build the world's largest ultra-lightweight aeroplane for research into the chemistry of stratospheric ozone. Named "Egret", the plane will be constructed from carbon and glass fibre materials by a company that normally manufactures sailplanes. It will enter service next year and will be capable of flying to altitudes of 15 kilometres. Despite its size, its wing span will be relatively small - just 30 metres - to minimize drag. Crew will be a pilot and a scientist, who will be accompanied by 1,000 kilos of scientific equipment.

J.N.

\section{Two satellites up}

JAPAN's National Space Development Agency successfully launched a communications satellite last Friday aboard an H-1 rocket. When the Sakura $3 b$ satellite is placed into geostationary orbit - in about 3 months - the way should be opened to commercial satellite services in Japan. A few days after the Japanese launch, Israel became the eighth nation capable of launching an indigenous satellite, orbiting a device principally designed for reconnaissance. Prime Minister Shamir called the success "a giant step making Israel a partner in the upper echelons in the technological world".

\section{Academy postpones}

THE general meeting of the Soviet Academy of Sciences scheduled for the end of this month (27 September) has unaccountably been postponed until the end of October, according to members of the Academy. The general meeting, one of three held each year, was intended to reach a number of important decisions about the management of its own affairs in the light of the Party Conference at the end of June (see Nature 335, 101; 1988).

\section{Edinburgh Festival II}

A NEW science festival will make its mark on the British public next year; to be held annually in Edinburgh, the festival will have much the same format as the British Association, though its director Howard Firth says it will be more community orientated. Funds of $£ 85,000$ have been raised from local authorities and commercial sponsorship; the target budget is $£ 250,000$. The theme of the first festival, to run from 3 to 12 April, is communications. C. McG. 